\title{
Imagologi Spiritual
}

\section{( Mengenang Kepemimpinan Kharismatik Pdt. Petrus Agung Purnomo)}

\author{
Oleh : Fibry Jati Nugroho
}

\begin{abstract}
ABSTRAK
Pendeta Petrus Agung Purnomo merupakan salah seorang tokoh yang fenomenal sewaktu hidup, maupun pada saat meninggalnya. Kepemimpinan kharismatis menjadikan salah satu faktor dari keberhasilan pelayanannya. Berkenaan dengan kepemimpinan tersebut, bagaimana imagologi yang ditampilkan dari sosok kharismatis tersebut? Dengan menggunakan pendekatan kualitatif didapatkan bahwa "anak didik" dari Sang Pemimpin kharismatik, melakukan imagologi dengan mengimitasi tindakan "atraktif" sewaktu melayani. Imitasi tersebut meliputi gaya bahasa, olah tubuh dan gaya berpakaian. Ketiga hal tersebut akhirnya menjadikan standar untuk mengukur tingkat kerohanian di kalangannya. Imagologi tanpa identifikasi dan interaksi yang tidak mendalam akan menimbulkan stigmatisasi spiritual dengan pemahaman yang sangat dangkal. Oleh sebab itu diperlukan interaksi dan edukasi, supaya imagologi spiritual dapat terkikis, dan mengembalikan makna dasar tentang kehidupan spiritual di dalam gereja.
\end{abstract}

Kata kunci: Imagologi, Kepemimpinan, Kharismatik, Imitasi, Spiritual

PENGANTAR

Dewasa ini, kehidupan manusia ber-kembang dengan pesat. Teknologi sebagai motor penggerak yang siap melaju dengan cepat seiring perkembangan dunia yang semakin menua. Perkembangan yang pesat membuat kehidupan masyarakat semakin "menggila", mengikuti arus perkembangannya. Hidup manusia yang kecanduan dan ketergantungan dengan teknologi, menggerus ke-hidupan sosialnya. Manusia menjadi egosentris dan acuh dengan kehidupan sesamanya. Alhasil, segala macam cara digunakan untuk mempertahan-kan kehidupannya.

Mengutip istilah yang dipopulerkan oleh Thomas Hobbes, Homo homini Lupus menjadi sebuah fakta sosial yang dapat dijumpai pada zaman sekarang. Dengan berbagai cara manusia berjuang untuk mempertahan-kan kehidupan, walaupun mengorban-kan sesamanya. Kehidupan sosial menjadi sebuah panggung pertunjuk-kan yang diperankan oleh manusia. Peran antagonis dan protagonis silih berganti diperankan oleh seseorang. Realitas sosial ini selaras dengan apa yang dipopulerkan oleh Aristoteles (350-429SM) yang dikenal dengan istilah dramaturgi.
Istilah ini kemudian ber-kembang dan menjadi sebuah grand teori yang diikuti oleh beberapa tokoh diantaranya Erving Goffman. Goffman memperkenalkan dramaturgi pertama kali dalam kajian sosial psikologis dan sosiologi melalui bukunya, "The Pre-sentation of Self In Everyday Life". Buku tersebut menggali segala macam perilaku interaksi yang dilakukan dalam pertunjukan kehidupan sehari-hari, yang menampilkan diri sendiri dalam cara yang sama dengan cara seorang aktor menampilkan karakter orang lain, dalam sebuah pertunjukan drama. Tujuan dari presentasi dari Diri-Goffman ini adalah penerimaan penonton akan manipulasi.

Konsep dramaturgi memungkinkan seseorang untuk mengembang-kan pola perilaku yang sesuai dan mendukung perannya. Interaksi antar individu yang dijadikan titik berat dari pengembangan konsep ini. Dalam interaksi tersebut individu dapat berperan memainkan perannya di panggung kehidupannya. Peran ter-sebut dapat berupa penokohan yang diikuti gestur dan mimik wajah sebagai pelengkapnya. Penokohan ini menjadi penting dan sering dilakukan oleh setiap orang. Dalam perkem-bangannya, dramaturgi berubah men-jadi sebuah imagologi yang banyak diperankan oleh para tokoh utama dalam kehidupan manusia. 
Imagologi merupakan sebuah konsep yang moncar "dihidupi" oleh manusia belakangan ini. Secara etimologis, imagologi berasal dari bahasa Yunani "imago" dan "logos". Imago mempunyai arti gambar atau gambaran dan logos mempunyai arti ilmu, kata atau perkataan. Dengan demikian gabungan dua kata tersebut mem-punyai pengertian ilmu yang mem-pelajari tentang gambar(an).

Istilah imagologi ini sendiri mulai diperkenalkan oleh novelis yang bernama Milan Kundera dalam tulisannya yang berjudul "Immorta-lity". Dalam tulisan tersebut ia menjelaskan bahwa imaji dan kenyata-an sudah saling tumpang tindih di dunia sekarang ini. Kundera ber-pendapat bahwa polling opini publik merupakan instrumen penting dari kuasa imagologis, karena polling memungkinkan imagologi untuk hidup berdampingan secara harmonis dengan masyarakat. Temuan dari polling telah menjadi realitas yang lebih tinggi dari yang real, atau menurut Kundera menjadi kebenaran, sebuah kebenaran yang paling demokratis dari yang pernah ada (Hudjolly, 2015).

Produksi imagologi dalam skala massif melibatkan pembenaran dalam hal penggunaan simbol ke-agamaan. Kontroversi teologis "baik dan buruk" disajikan lewat simbol-simbol menjadikan pertentangan ke-duanya bersifat absurd. Agama sering dinilai dari realitas yang tampak luar, yang dalam proses imagologi dibuat dalam bentuk teks-teks, penokohan, dan produksi retorika, sehingga perilaku keagamaan selalu diukur pada simbol yang mewakili realitas yang ditampakkan. Imagologi merupakan representasi visual dan naratif, jadi yang dikedepankan adalah citra, mediumnya adalah media massa, media sosial dan pentas panggung yang melibatkan terkumpulnya massa.

Iklan-iklan komersial dan propaganda ideologis melalui pang-gungpanggung pentas, menurut Milan Kundera, merupakan bagian dari satu aturan yang sama, yakni: imagologi. Kata ini mencakup "agensi periklanan dan pembujukkan masssa dan juga disebut sebagai manajer kampanye politik". Dalam bidang keagamaan, imagologi sebagai dapat digunakan untuk (me)rekayasa teks, terutama untuk membenarkan dan menggiring opini massa ke dalam kehendak sang imagologis. Teks yang tertulis dalam kitab keagamaan acapkali akan di-tafsirkan melalui gerak dan olah fisik sang penafsir menjadi tindakan sim-bolik imagolog. Simbol-simbol yang nampak akan menjadikan sebuah inter-aksi simbolik yang menarik bagi para penerimanya.

Interaksionisme simbolik sen-diri dimulai dari Amerika terutama di bawah pengaruh paham pragmatis. Interaksionisme simbolik bercirikan sikap (attitude) dan arti (meaning). Interaksionisme simbolik berorientasi pada diri atau pribadi (personality). Istilah interaksionisme simbolik di-gunakan pertama kalinya oleh Herbert Blumer, yang pada dasarnya me-rupakan satu perspektif psikologi sosial. Perspektif ini memusatkan per-hatiannya pada analisa hubungan antar pribadi. Individu dipandang sebagai pelaku yang menafsirkan, menilai, mendefinisikan, dan bertindak (Abbott , Wallace and Tyler, no date).

$$
\text { Georg Simmel berpandangan }
$$

bahwa muncul dan berkembangnya kepribadian seseorang tergantung pada jaringan hubungan social yang dimilikinya, yaitu pada keanggotaan kelompoknya. Di sisi lain Max Weber memperkenalkan interaksionisme de-ngan menyatakan bahwa sosiologi ialah ilmu yang berusaha memahami tindakan sosial dengan mendefinisi-kan dan membahas konsep dasar yang menyangkut interaksi seperti tindakan, tindakan sosial dan tindakan non sosial, serta hubungan sosial (Giddens, no date).

Tokoh sosiologi modern yang berasal dari Amerika Serikat yang merintis pemikiran dasar mengenai interaksionisme adalah Wiliem James, Charles Harton Cooley, John Dewey dan George Herbert Mead. Ide-ide mereka kemudian mempengaruhi ang-katan ahli sosio-logi 
yang lebih muda seperti Herbert Blumer, Erving Goff-man, dan Peter L. Berger. Di antara para pengikut teori interaksionisme simbolik terdapat perbedaan pandang-an, tetapi mereka sepakat mengenai beberapa hal yaitu: (1) terdapat ke-sepakatan bahwa manusia merupakan mahkluk yang mampu menciptakan dan menggunakan simbol, (2) manusia memakai simbol untuk saling berkomunikasi, (3) manusia berkomunikasi melalui pengambilan peran (role taking), (4) masyarakat tercipta, bertahan, dan berubah ber-dasarkan kemampuan manusia untuk berpikir, untuk mendifinisikan, untuk melakukan renungan dan untuk me-lakukan evaluasi (Best, 2003).

Ide-ide dasar interaksionisme simbolik yaitu: manusia terdiri dari masyarakat yang berinteraksi. Interaksi terdiri dari berbagai kegiatan manusia yang berhubungan dengan kegiatan manusia yang lain. Obyek-obyeknya tidak mempunyai makna intrinsik, sebab makna lebih merupakan produk interaksi simbolis. Manusia tidak hanya mengenal obyek eksternal, tetapi mereka dapat melihat dirinya sebagai obyek.

Tindakan manusia adalah tindakan interpretatif yang dibuat oleh manusia itu sendiri. Tindakan tersebut saling berkaitan dan disesuaikan oleh anggota-anggota kelompok. Secara ringkas teori interaksi simbolik dapat dipahami dalam tiga tema besar, yaitu:

1. Interaksi simbolik berfokus pada pentingnya membentuk makna bagi perilaku manu-sia, dimana dalam teori interaksi simbolik tidak bisa dilepaskan dari proses ko-munikasi, karena awalnya makna itu tidak ada artinya, sampai pada akhirnya di konstruksi secara interpretif oleh individu melalui proses interaksi, untuk menciptakan makna yang dapat disepakati secara bersama.

2. Interaksi simbolik berfokus pada pentingnya "Konsep diri" atau "Self-Concept". Dimana, pada tema interaksi simbolik ini menekankan pada pengembangan konsep diri melalui individu tersebut secara aktif, didasarkan pada interaksi sosial dengan orang lainnya.

3. Interaksi simbolik berkaitan dengan hubungan antara kebebasan individu dan masyarakat, dimana asumsi ini mengakui bahwa norma-norma sosial membatasi peri-laku tiap individunya, tapi pada akhirnya tiap individu-lah yang menentukan pilihan yang ada dalam sosial kemasyarakatannya.

Ketiga tema ini yang kemudian menjadi produsen sang imagolog mengkonstruksi proyek imagologinya. Apabila menelisik ke dalam kehidupan spiritual, akan didapati banyak kontruksi imagologis yang berasal dari tindakan-tindakan simbolik sang agen. Tindakan-tindak-an simbolik itu untuk kemudian menjadikan sebuah dramaturgi yang diperankan secara apik dan menarik dalam pentas spiritualitas.

Hal yang menarik untuk diamati dengan memakai kacamata imagologi adalah praktik kepemimpin-an Alm. Pdt. Petrus Agung Purnomo dalam menjalankan megachurch di Semarang. Kepemimpinan yang kharismatis dan penuh dengan simbolsimbol yang menyertainya, menarik untuk dikaji. Pertanyaannya bagai-mana imagologi spiritual dalam kepemimpinan Pdt. Petrus Agung Purnomo?

\section{METODE}

Dalam penelitian ini pendekatan yang digunakan bersifat kualitatif. Ini dikarenakan perhatian yang diberikan oleh pendekatan ini kepada individu-individu dan situasi hidup mereka. (Berg, 2001) Serta kemampuannya untuk memberikan gambaran rinci dan mendalam tentang suatu peristiwa atau perilaku orang atau kelompok orang di suatu masa dan tempat tertentu. (Satori and Komariah, 2010) 
Pusat perhatian-nya bukan pada data-data kuantitatif atau angka-angka melainkan pada data-data tekstual dan kisah-kisah subyek yang diteliti, (Auerbach and Silverstein, 2003) pada emosi-emosi mereka, motivasi-motivasi, simbol-simbol dan maknanya, serta aspek-aspek subyektif lain sebagaimana tampil dalam perilakuperilaku sehari-hari, dalam pengalamanpengalaman-nya dan dalam berbagai kondisi yang mempengaruhi hal-hal rutin dan alami buat mereka. (Berg, 2001)

Penelitian ini mengkaji fase yang telah lampau dan juga kehidupan masa kini. Untuk ini diperlukan strategi dalam memanfaatkan sumber in-formasi, guna mendapatkan data yang akurat dan mendalam. Untuk me-ngetahui kehidupan masa lampau dilakukan penelitian dokumen, guna menelisik kehidupan yang terjadi di masa lalu. Data yang bersifat kekinian diperoleh lewat wawancara kepada masyarakat, yang disertai dengan pengamatan langsung atau terlibat di dalamnya.

Peneliti memilih menggunakan partisipatif pasif dalam penggalian data, dengan hidup bersama dengan informan. Dengan beraktifitas bersama dengan informan, maka akan didapat-kan data yang orisinal, tanpa ada rekayasa dari informan, sehingga dapat diketahui dengan jelas halhal yang samar-samar.

Dalam penulisan ini, analisis data dilakukan dengan analisis des-kriptif kualitatif. Teknik ini meng-gambarkan dan menginterpretasikan arti data-data yang telah terkumpul dengan memberikan perhatian dan merekam sebanyak mungkin aspek situasi yang diteliti pada saat itu, sehingga memperoleh gambaran se-cara umum dan menyeluruh tentang keadaan sebenarnya. Hasil kajian analisis ini mendapatkan sebuah gambaran utuh, sistematis, faktual dan akurat tentang faktafakta dalam hubungannya dengan fenomena yang diselidiki.

Dalam mensintesakan data yang telah didapat, baik berupa hasil wawancara, catatan lapangan, doku-mentasi, dan hasil pengamatan, maka ada beberapa langkah analisis data yang diterapkan pada penelitian ini. Adapun lang-kahnya adalah sebagai berikut (Sugiyono, 2012):

a. Data reduction (Reduksi data)

Data yang telah dikumpulkan membutuhkan catatan yang teliti dan rinci. Semakin banyak jum-lah data, maka semakin rumit dan kompleks untuk merang-kumnya. Oleh sebab itu diper-lukan kecermatan dalam memilih hal-hal yang pokok, sesuai dengan tujuan penelitian ini. Data yang telah tereduksi ber-dasarkan kerangka penelitian ini, dapat memberikan gambaran dengan lebih jelas.

b. Data Display (Penyajian Data)

Data yang telah direduksi di-sajikan secara kualitatif. Sajian data ini berupa uraian singkat, hubungan antar kategori, flow-chart dan juga sejenisnya. Namun, lebih sering digunakan narasi untuk menyajikan data tersebut, mengingat ini merupakan penelitian kualitatif.

c. Conclusion Drawing / Verivica-tion (Kesimpulan dan verifikasi)

Kesimpulan awal dalam sebuah penelitian masih bersifat se-mentara, dan berubah apabila menemukan bukti yang kuat untuk mengugurkan simpulan tersebut. Untuk menghasilkan kesimpulan yang kredibel, di-perlukan bukti-bukti yang valid dan konsisten saat kembali turun ke lapangan dalam rangka pengumpulan data.

Hasil dari analisis data tersebut, kemudian disajikan secara kom-prehensif untuk dapat menampilkan hasil penelitian yang telah terverifikasi dan tervalidasi.

\section{PEMBAHASAN}

Cikal bakal Gereja Jemaat Kristen Indonesia Injil Kerajaan berasal dari persekutuan doa yang dibangun oleh anakanak muda. Ke-gerakan anak-anak muda ini berawal dari kebaktian kebangunan 
rohani di Semarang pada tahun 1979. Wisma Pandanaran menjadi saksi pertobatan, lebih dari 400 pelajar yang menyerah-kan hidupnya untuk dibarui oleh Tuhan Yesus (Budianto, 2009). Mereka bertobat dan membuat komit-men untuk sungguh-sungguh me-layani Tuhan dengan segenap hati-nya. Kebaktian kebangunan rohani saat itu, merupakan titik balik bagi ratusan orang dalam kehidupan pribadinya.

Kegiatan ini berlanjut dengan diadakannya acara Malam Anugrah pada bulan Agustus 1979 di Wisma Pancasila (Budianto, 2009). Acara ini dikemas dengan sedemikian rupa, sebagai wadah tempat berkumpulnya anak-anak muda yang haus akan hadirat Tuhan. Hal yang di luar dugaan terjadi melalui acara ini. Tercatat lebih dari 2000 anak muda menyerahkan hidupnya melalui tiga hari KKR yang luar biasa (Budianto, 2009). Beberapa di antaranya menyerahkan hidupnya untuk melayani Tuhan sepenuh waktu.

Banyak tokoh-tokoh gereja yang dilahirkan pada acara Malam Anugrah tahun 1979. Beberapa di antaranya telah menjadi pemimpin-pemimpin gereja pada masa kini. Adapun tokoh-tokoh itu antara lain adalah Pdt. Adi Sutanto (Ketua Sinode Jemaat Kristen Indonesia), Ir. Ryanto Sindoro, M.Div (Direktur IFGF GISI Regional USA dan Canada), Jimmy Oentoro, D.Th (Ketua Sinode IFGF GISI), serta Pdt. Petrus Agung Purnama yang menjadi perintis dan pemimpin dari gereja Jemaat Kristen Indonesia Injil Kerajaan Semarang.

Petrus Agung mendapat lawatan Tuhan untuk memberitakan injil kepada banyak orang. Ia menjadi penggerak anakanak muda di Se-marang melalui Persisko (Persekutuan Siswa/siswi Kristen Oikumene). Persekutuan doa inilah yang menjadi embrio lahirnya persekutuan doa yang lebih besar, yaitu Persekutuan Doa Sangkakala (PD. Sangkakala). Saat itu, PD Sangkakala berdomisili di gedung Pemuda Semarang. Pada kelanjutan-nya, persekutuan doa ini bertambah besar dan berubah menjadi gereja Jemaat Kristen Injil Kerajaan pada awal tahun 1991 (Nugroho, 2003).

Pada masa perintisan awal, jemaat yang hadir hanya sekitar puluhan orang saja. Namun, seiring dengan berjalannya waktu, jemaat yang hadir bertambah semakin banyak. Kapasitas gedung yang ada pun mulai tidak sebanding dengan jumlah jemaat. Para pemimpin gereja, terutama Pdt. Petrus Agung Purnama mulai ber-gumul untuk mendapatkan gedung baru yang dapat menampung jumlah jemaat yang ada.

Alhasil, pada tahun 1992 gedung Roller Skate di Pondok Hasanudin diijinkan dipakai untuk ibadah setiap minggunya. Gedung itu mampu memuat 1000 jemaat dalam satu kali ibadah. Banyak orang yang terberkati dengan keberadaan gereja tersebut. Hasilnya peningkatan jumlah jemaat pun tidak dapat terelakkan. Pada tahun 1994, gedung di Pondok Hasanudin mulai direnovasi, sehingga dapat menampung 1600 orang dalam setiap ibadahnya (Nugroho, 2003).

Seiring dengan berjalannya waktu, pergerakkan JKI Injil Kerajaan semakin kuat di Semarang. Pdt. Petrus Agung Purnama menuturkan bahwa gereja JKI Injil Kerajaan yang Tuhan percayakan, telah masuk hampir di seluruh sektor kehidupan masyarakat kota ini. Pemerintahan Illahi mulai terbayang dengan jelas dalam mem-berkati 2 juta penduduk Semarang (Budianto, 2009). Jumlah jemaat se-makin meningkat, sehingga gedung yang berkapasitas 1600 orang tersebut sudah terasa sempit. Para pemimpin gereja mulai bergumul dan mencari lokasi pembangunan gedung yang baru.

Pada bulan April tahun 2002, Pdt. Petrus Agung mendapatkan tanah seluas 2,8 hektar di daerah Marina Semarang. Bulan Mei pada tahun yang sama, terjadilah negosiasi berkaitan dengan pembelian tanah tersebut. Ber-selang lima hari kemudian, ijin pem-bangunan gereja pun telah keluar dari pemerintah kota 
Semarang. Sembilan bulan kemudian tanah telah lunas dibayar. Akhirnya, tahun 2003 di-lakukan peletakan pondasi dan pembangunan gedung gereja baru dilaksanakan. Pada tahun 2004, gereja ini telah selesai dibangun dan mampu menampung 12.000 orang dalam se-tiap ibadahnya (Nugroho, 2003). Gedung ini diberi nama Holy Stadium, mengingat kapasitasnya yang ekstra besar dalam menampung jemaat.

Gereja yang mempunyai jemaat begitu banyak, tidak pernah lengang dalam kesehariannya. Kegiatan-kegiat-an yang berlangsung dalam aktivitas-nya seharihari merupakan program gereja dalam memberdayakan jemaat-nya. Kantor gereja selalu sibuk mem-persiapkan programprogram yang akan dijalankan bagi jemaatnya. Namun, yang kegiatan ibadah-nya hanya dilakukan tiga kali dalam satu minggu. Ibadah pertama diadakan pada hari Sabtu pukul 18.00 WIB. Untuk ibadah kedua dan ketiga dilaksanakan pada hari Minggu pukul 07.00 WIB dan 17.00 WIB. Ibadah yang diadakan pada setiap minggunya merupakan sebuah pelayanan pastoral umum bagi semua anggota jemaatnya.

Kebaktian untuk anak kecil atau biasa yang disebut dengan ibadah sekolah minggu memiliki jadwal ter-sendiri yang dibagi dalam tiga sesi, yaitu :

a. Sesi pertama : Ibadah Sabtu Ceria pada hari Sabtu pukul 16.00 WIB

b. Sesi kedua : Sekolah Minggu Pagi pada hari Minggu pukul 07.00 WIB dan 10.00 WIB

c. Sesi ketiga : Sekolah Minggu Sore pada hari Minggu pukul 17.00 WIB Di samping kegiatan ibadah anak tersebut, tidak jarang JKI Injil Kerajaan mengadakan acara khusus untuk anak-anak, baik pada perayaan Natal, Paskah maupun hari Anak Nasional. Berbagai acara ini diadakan sebagai sarana untuk menumbuhkembangkan spiritualitas dan sosialitas anak sejak dini.

JKI Injil Kerajaan berusaha membuat setiap kegiatan yang ada di dalam gereja menjadi stimulan bagi jemaat dalam menggembangkan diri-nya, baik secara spiritual maupun sosial. Secara spiritual gereja me-nyelenggarakan berbagai ibadah se-bagai sarana untuk berinteraksi dengan Tuhan. Tidak jarang setiap kegiatan spiritual disertai dengan manifestasi dari kuasa Roh Kudus. Untuk mengakomodasi kehidupan sosial jemaat, gereja menyelenggarakan pasar murah. Adapun tujuan kegiatan ini merupakan sebuah upaya agar jemaat dapat bersentuhan langsung dengan orang-orang lain secara interculture dan interreligion.

Beberapa bulan terakhir ini, gereja juga menyelenggarakan ke-giatan yang bekerja sama dengan pemerintah kota, sebagai wujud kepedulian gereja dengan perkem-bangan kota Semarang. Kegiatan ini juga merupakan sebuah sarana gereja untuk memberi stimulan kepada jemaat agar mencintai kotanya. Kegiatan terbaru dari gereja adalah mengutus anak-anak muda ke berbagai provinsi di Indonesia guna menyuara-kan kembali sumpah pemuda. Kegiat-an ini merupakan sebuah langkah maju gereja untuk menumbuhkan jiwa nasionalismenya.

Di sisi yang lain, Pdt. Petrus Agung (Alm) sebagai pendeta senior di JKI Injil Kerajaan sangat meng-hayati proses karya Roh Kudus bagi dan dalam gerejanya. Di dalam salah satu bukunya yang berjudul Bebas dari Jerat Hutang, ia menguraikan bagaimana perjalanan pelayanannya dalam rangka menumbuhkan jemaat JKI Injil Kerajaan. Ia memberi per-nyataan, bahwa roh-Nya sendiri yang selama ini bekerja dengan kuat di tengah-tengah umat-Nya (Purnomo, 1996). Atas dasar inilah, hampir semua kegiatan pelayanan di JKI Injil Kerajaan bernafaskan kegerakan Roh Kudus yang kental di dalamnya. Ada-pun beberapa kegiatan pelayanannya adalah :

1. Kebaktian kebangunan rohani (KKR), kegiatan ini merupakan salah satu ciri khas dalam pelayanan di JKI Injil Kera-jaan. Hampir setiap Minggu diadakan ibadah kebangunan rohani bagi jemaat 
umum. Ibadah ini diadakan dengan tujuan membangkitkan iman para jemaat serta sebagai ajang pendemonstrasian kuasa roh kudus. Ibadah KKR acapkali disertai dengan praktik ke-sembuhan illahi. Bagi jemaat dan orang yang hadir dapat didoakan untuk mendapatkan kesembuhan atas penyakitnya. Hasilnya, banyak orang yang mendapatkan kesembuhan de-ngan kuasa doa. Bercermin dari kesuksesan ini, pelayanan KKR dilakukan pula di kota-kota yang lain. Mulai dari Kudus, Pati, Temanggung dan kota lain di Jawa Tengah. Kegiatan ini membawa dampak bagi pertumbuhan jumlah jemaat di gereja JKI Injil Kerajaan.

2. Misi, kegiatan pelayanan lain-nya yang dikembangkan oleh JKI Injil Kerajaan adalah penginjilan dan bermisi ke tempat-tempat lain. Tahun 1996, diadakan kegiatan misi ke daerah Kalimantan Tengah. Satu keluarga diutus untuk menginjil ke suku Dayak Siang, tepatnya di Kabupaten Purukcahu. Hasilnya, sekarang telah ada dua belas gereja cabang di daerah Kalimantan Tengah. ${ }^{1}$ Melihat hasil yang signifikan, kegiatan misi dilanjutkan dengan pengutusan volunter-volunter ke berbagai daerah, diantaranya Kamboja, Hongkong, Palau, dan Viet-nam. Baru-baru ini, sering diadakan mission trip di ber-bagai daerah baik di dalam dan di luar negri, sebagai upaya melatih jemaat bermisi seka-ligus memberitakan kabar ke-selamatan bagi banyak orang. Dari kegiatan misi, nama JKI Injil Kerajaan dikenal di ber-bagai tempat.

3. Rumah Damai, kegiatan pe-layanan ini berbentuk lembaga sosial yang

${ }^{1}$ Diolah dari VCD Building Your Life " JKI Profile”, Life Production 2003, Media JKI Injil Kerajaan menangani masalah narkoba. Mulyadi Irawan ada-lah pemimpin dan penggerak pelayanan ini. Ia mempunyai kerinduan untuk menyelamat-kan orang-orang yang kecan-duan narkoba. Pelayanan ini didasari dengan keinginan untuk menolong para pecandu narkoba agar dapat kembali hidup normal. Berbagai prog-ram telah disiapkan untuk dapat menolong mereka dari jerat narkoba. Hasilnya, banyak orang yang telah berhasil dilepaskan dari narkoba dan dapat kembali ke tengah masyarakat.

4. Radio Rhema, JKI Injil Kerajaan mulai melebarkan sayapnya untuk meram-bah di dunia radio. Radio ini mulai mengudara pada bulan Maret 2001. Pelayanan ini didasari atas visi yang terdapat dalam Yesaya 61 . Sugiarto Suwondo yang didaulat sebagai Direktur Operasional dari radio Rhema, menuturkan bahwa dengan adanya radio, diharapkan akan ada banyak orang yang mendengar kabar keselamatan dan dapat termotivasi dengan siaran yang membangun hidupnya.

5. Toko Buku Rhema, pelayanan literatur diadakan sebagai sarana memberikan bacaan yang berbobot sekaligus dapat memberikan 'asupan gizi' bagi kebutuhan spiritual jemaat.

6. Media Injil Kerajaan, pelayan-an ini merupakan sebuah wadah untuk memproduksi beragam media yang dapat membantu jemaat dalam mene-mukan buku-buku berserta dengan literatur elektronik yang berbobot bagi kebutuhan spiritual jemaat. Pada perkem-bangannya, media injil ke-rajaan telah merambah di dunia pertelevisian. Life TV merupa-kan layanan televisi lokal yang dapat diakses 
pula melalui fasilitas streaming. Pelayanan televisi ini dimaksudkan agar masyarakat mendapat sajian tontonan yang edukatif sekali-gus spiritual. Melalui media televisi dan media yang lain-nya, diharapkan akan lebih banyak orang lagi yang dapat mendengar kabar baik dari Tuhan.

7. The School Of Acts (TSOA), pelayanan ini merupakan se-buah wadah yang menampung orangorang untuk mendapat-kan pengajaran spiritual dari para pemimpin rohani. Para pengajar yang diundang me-rupakan orangorang yang telah sukses di bidang ke-hidupannya.

8. Balai pengobatan, sarana ini dibangun sebagai wujud kepedulian gereja terhadap ke-sehatan jemaat dan warga yang ada di sekitar gereja. Para jemaat dan warga dapat berobat dengan biaya terjangkau dengan fasilitas pengobatan yang memadai.

9. Toko warga, pelayanan ini merupakan wujud kasih dari gereja kepada warga kurang mampu. Jemaat yang mampu dapat menyumbang jemaat lain berupa sembako dan barang ke-butuhan rumah tangga yang lain. Jemaat dan warga yang kurang mampu dapat membeli kebutuhan pokok di toko ini dengan harga lebih murah di bawah pasar. Sekitar 1000 paket sembako dijual setiap bulannya untuk warga yang membutuhkan.

10. Anak asuh, program pelayanan ini merupakan sebuah sarana untuk membantu jemaat yang kurang mampu dalam mem-bayar sekolah anaknya. Pro-gram ini dimulai pada tahun 1998 yang diawali dengan bantuan sekolah bagi warga jemaat saja. Pada perkem-bangannya, warga sekitar yang membutuhkan juga dibantu dalam program anak asuh. Ke-giatan ini menunjukkan respon kasih dari gereja kepada jemaat dan warga sekitar.

11. Holy Café, gereja juga menyediakan café sebagai sarana dalam membantu jemaat yang hobi jajan. Di samping itu, café ini merupakan lapangan pe-kerjaan baru bagi jemaat yang membutuhkannya.

12. Yayasan Pendidikan Terang Bangsa, melalui yayasan ini, gereja JKI Injil Kerajaan membangun sekolah mulai dari Play Grup sampai setingkat Perguruan Tinggi (Akademi). Bagi warga kurang mampu, sekolah ini menyediakan pro-gram beasiswa penuh sampai selesai studi. Namun, bagi warga dan jemaat yang mampu diwajibkan membayar sesuai dengan aturan sekolah yang ada. Melalui sekolah ini, banyak orang terselamatkan dari putus sekolah karena ketiadaan biaya.

13. Sekolah Sepak Bola Terang Bangsa, wadah ini merupakan sebuah tempat untuk menyalur-kan hobi para anak muda yang hobi bermain sepak bola. Menurut penuturan pengurus-nya, sekolah bola ini dirancang untuk mendidik para pemain sepak bola yang bukan hanya mempunyai skill, namun juga mempunyai karakter fair play dalam setiap pertandingannya.

14. The School of Life (TSOL), ragam pelayanan ini merupa-kan bentuk kepedulian gereja kepada orang yang kurang ber-untung, khususnya berpenyakit mental. Orang-orang yang ber-penyakit mental ditampung di sebuah rumah tinggal untuk dapat dididik dan dirawat di sana. Alhasil, telah ada be-berapa penderita schzophrenia yang sembuh dan menjadi volunter di tempat itu untuk dapat merawat sesamanya pula.

15. Lembaga Pelatihan Kerja, tempat ini merupakan sarana gereja untuk 
dapat member-dayakan jemaat, sekaligus da-pat meningkatkan status eko-nominya. Dalam pelatihan ini, gereja memfasilitasi jemaat yang mampu dan mempunyai skill agar dapat melatih jemaat yang belum mempunyai skill. Pada perkembangannya, lembaga pelatihan ini dibuka pula untuk umum sebagai langkah memberkati dan memberdaya-kan orang-orang yang ada di sekitar gereja. Bagi orang yang benar-benar tidak mampu membayar biaya pelatihan, maka gereja membebaskan biaya secara keseluruhan. Bah-kan apabila ada orang yang mengalami kesulitan transport-tasi, gereja juga menyediakan sarana transportasi gratis bagi para siswa di lembaga pelatih-an kerja tersebut. Ini semua dilakukan sebagai bentuk pelayanan pemberdayaan bagi para warga masyarakat di Semarang.

16. Lembaga Bantuan Hukum (LBH Mawar Sharon), pe-layanan ini dibentuk sebagai wujud kepedulian gereja atas ketidakberpihakan hukum ke-pada masyarakat kecil. Para Sarjana Hukum yang ada di gereja membentuk lembaga ini dan bermitra dengan pengacara ternama yaitu Hotma Sitompul sebagai wadah yang melayani kebutuhan hukum dari para jemaat, ataupun orang yang meminta pertolongan di bidang hukum. Bantuan hukum akan diberikan secara cuma-cuma oleh lembaga ini, bila ada orang yang benar-benar mem-butuhkan.

17. Pertanian, ragam pelayanan ini merupakan bentuk keprihatinan gereja terhadap penghasilan pertanian di Semarang khusus-nya dan di Indonesia pada umumnya. Oleh sebab itu, gereja berusaha merangkul para ahli pertanian dan mem-fasilitasi untuk dapat membuka ladang jagung sebagai percontohan bagi para petani.
Hasilnya, sampai saat ini sudah banyak ladang pertanian dibuka baik di Jawa Tengah maupun kotakota lainnya, dengan panen yang umumnya ada di atas rata-rata.

Beberapa ragam pelayanan tersebut di atas merupakan sebuah alat dalam melayani dan membawa jemaat untuk dapat lebih dekat kepada Tuhan, serta mengalami perubahan di dalam hidup-nya. Alhasil, secara kuantitas jumlah jemaat di gereja JKI Injil Kerajaan mengalami peningkatan yang signifi-kan.

\section{Ciri Khas Kepemimpinan Kharis-matis JKI Injil Kerajaan}

Struktur kepemimpinan di JKI Injil Kerajaan memposisikan Gembala Sidang sebagai pimpinan tertinggi, dan dalam pelaksanaannya dibantu oleh empat orang pendeta yang menangani seluruh ragam pe-layanan yang ada. Dalam pengelolaan jemaatnya, pendataan memakai Nomor Induk Jemaat (NIJ) yang akan me-mudahkan membaginya ke dalam setiap kelompok sel (Mezbah Keluarga). Di dalam kelompok sel ter-sebut akan dilayani atau diketuai oleh seorang ketua sel. Ketua sel inilah yang bertugas memimpin dan meng-gembalakan anggota selnya. Gembala sidang sangat jarang bersentuhan langsung dengan jemaatnya, meng-ingat jumlah jemaat yang sudah mencapai ribuan orang. Tugas ketua sel yang mendistribusikan kebijakan, pengajaran dan nilai-nilai dari Gem-bala ke jemaatnya.

Apabila menelisik lebih jauh, gembala sidang JKI Injil Kerajaan merupakan pemimpin yang sangat kharismatis. Aura dan gaya ke-pemimpinan kharismatik dapat dilihat dan dirasakan dalam setiap khotbah, dan penampilannya di mimbar gereja setiap minggunya. Tindakan-tindakan simbolik acapkali bertebaran setiap kali ia mempimpin ibadah. Dimulai dari setiap pelafalan yang khas, sampai dengan jubah/pakaian yang dikenakan-nya mengandung makna simbolik yang mendalam. Kekhasan inilah 
yang kemudian menjadikan sebuah tafsir simbolik yang beragam dalam kepemimpinan Pdt. Petrus Agung Purnomo.

Tindakan simbolik yang "diatraksikan" di mimbar gereja acapkali menuai multitafsir dari jemaat. Alhasil, banyak didapati para pemimpin sel yang menduplikasi tindakan simbolik tersebut tanpa memahami makna yang mendalam. Duplikasi simbolik tersebut akhirnya menghasilkan imitasi, tanpa mengidentifikasi lebih dalam makna tindakan simbolik. Imitasi inilah yang kemudian melahirkan imagologi di kalangan pemimpin-pemimpin sel, se-bagai akibat kekaburan makna sim-bolik yang ditampilkan di mimbar gereja, oleh pemimpin-pemimpin gereja. Beberapa hal dapat dilihat imagologi sebagai "anak didik" dalam melakukan imitasi simbolik diantara-nya:

1. Gaya bahasa : para pemimpin sel banyak yang menirukan warna suara dari pemimpinnya, dengan suara yang agak berat dan lantang. Di samping itu, gaya bahasa eskatologis yang sering diutarakan oleh sang pemimpin, kerap diutarakan pula oleh pemimpin sel. Gaya bahasa eskatologis inilah yang acapkali menuai kontroversi, karena diucapkan tanpa pe-mahaman yang mendalam, dan sering digunakan untuk ajang imagologi di "mimbar kecil" yang dibuat oleh pemimpin sel.

2. Olah tubuh : Gerak tubuh sang pemimpin sangat khas ketika berada di atas mimbar. Baik ketika berdoa, mengangkat tangan, penyembahan maupun saat berkhotbah sangatlah khas dimiliki oleh pemimpinnya. Oleh para pemimpin sel dan beberapa jemaat lain, olah tubuh yang khas inilah yang kemudian menjadi viral untuk diimitasi dalam setiap kegiatan ritual keagamaannya. Olah tubuh inilah yang kemudian diimitasi dan dipakai standar untuk menentukan "kadar rohani" dari seseorang. Dari hal ini, mulailah imagologi terjadi dan dibentuk sebagai wujud kehidupan spiritualnya.

3. Gaya berpakaian : gaya berpakaian dari pemimpinnya menjadi tren tersendiri bagi dunia mode di jemaatnya. Se-tiap pakaian yang dikenakan oleh pemimpin tertinggi ter-sebut membuat produsen yang membuatnya kebanjiran order. Gaya berpakaian ini juga kerap diimitasi oleh para pemimpin sel, agar mereka terlihat berwibawa dan "rohani" seperti pe-mimpinnya.

Hal-hal tersebut di atas merupakan sebuah imitasi yang menjadi viral di kalangan pemimpin sel JKI Injil Kerajaan. Imitasi tanpa identifikasi yang dalam akan memunculkan imagologi di kalangan pemimpin sel. Imitasi tersebut lantas menimbulkan stigma tentang kadar rohani dari seseorang. Orang yang dianggap "rohani" adalah orang yang me-lakukan seperti yang dilakukan Pdt. Petrus Agung Purnama di mimbarnya. Di luar dari itu, kalangan jemaat menganggap "kurang rohani”. Imago-logi spiritual inilah yang kemudian berkembang di kalangan "pengikut" mazhab pemimpinnya. Imagologi tanpa identifikasi dan interaksi yang tidak mendalam akan menimbulkan stigmatisasi spiritual dengan pe-mahaman yang sangat dangkal.

\section{KESIMPULAN}

Imagologi lahir dari embrio imitasi dari sebuah interaksi yang kurang mendalam. Agen pemroduksi simbol melahirkan simbol-simbol penuh makna, tetapi penerima simbol kurang dapat memahami makna secara mendalam. Diperlukan jembatan se-bagai sarana interaksi yang mendalam untuk mendekatkan jurang pemisah diantaranya. Jembatan komunikasi perlu dibangun di dalamnya, supaya makna simbolik yang 
ditampilkan ditangkap secara utuh dan menyeluruh.

Komunikasi lebih intens antara pemimpin jemaat dengan pe-mimpin sel, dapat memudarkan multi-tafsir di kalangan jemaatnya. Ini di-perlukan mengingat pendeta yang di-posisikan sebagai pemimpin tertinggi gereja jarang berkomunikasi langsung dengan pemimpin sel. Ketua sel hanya menerima informasi dari orang kedua atau ketiga, sehingga informasi yang diterima cenderung bias, dan sudah tidak sesuai dengan aslinya. Komuni-kasi yang intens dan mendalam dapat memudarkan imitasi dan imagologi di kalangan jemaat, hasilnya akan meningkatkan pemahaman makna tentang tindakan simbolik pemimpin kharis-matik tersebut.

Di samping komunikasi, diperlukan informasi yang mendalam dalam rangka memudarkan imagologi di kalangan spritualis. Informasi yang mendalam dapat dimaknai dengan menambah pengetahuan melalui pem-bukaan kelas-kelas pembelajaran yang difasilitasi oleh pihak gereja. Kelas-kelas tersebut dipakai sebagai sarana memperluas cakrawala pengetahuan dan peningkatan pemahaman yang mendalam terkait dengan nilai, dan makna simbol-simbol yang menjadi ciri khas di dalam gereja. Di dalam kelas-kelas tersebut akan dapat meng-identifikasi makna simbolis, bukan hanya imitasi dari tindakan simbolis.

Kelas pengajaran bagi ketua sel, menjadi langkah awal membekali pemimpin sel, agar dapat menambah pengetahuan, untuk kemudian memviralkan pengetahuan tersebut kepada anggota selnya. Ketika pengetahuan meningkat, dan pemahaman tentang makna simbolis terdistribusi dengan baik, imagologi spiritual di kalangan jemaat lambat laun akan memudar. Anggota jemaat tidak dengan mudah mengimitasi tindakan simbolik, akan tetapi dapat mengidentifikasi lebih jauh dan bonusnya jemaat akan menjadi ujung tombak pelayanan gereja, untuk menyebarkan nilainilai yang menjadi ciri khas gereja.

Alternatif solusi tersebut di atas dapat menjadi sebuah pintu masuk mengikis imagologi spiritual di dalam sebuah kepemimpinan kharismatik di gereja. Imagologi spiritual dihasilkan dari imitasi tanpa identifikasi yang mendalam dari sebuah tindakan sim-bolik. Apabila imagologi spiritual ber-kembang, maka ritual keagamaan tidak berbeda dengan pentas drama di panggung-panggung hiburan.

Orang yang ada di mimbar agama hanya bermain peran dengan memproduksi tindakan simbolik, sebagai penguatan ritual keagamaan-nya. Dramaturgi yang terjadi di panggung mimbar ritual keagamaan, menjadikan makna spiritual yang terkandung di dalamnya memudar. Alhasil, kehidupan spiritual menjadi hampa tanpa makna. Oleh sebab itu, diperlukan komunikasi yang efektif dan penyebaran pengetahuan yang merata, agar imagologi spiritual dapat terkikis, dan mengembalikan makna dasar tentang kehidupan spiritual di dalam gereja. 


\section{DAFTAR PUSTAKA}

Abbott, P., Wallace, C. and Tyler, M. (no date) 'An Introduction to Sociology'.

Auerbach, C. F. and Silverstein, L. B. (2003) An Introduction to Coding and Analysis Qualitative Data. New York: New York University Press.

Berg, B. L. (2001) Qualitative Reseacrh Methods for Social Sciences. MA: Allyn \& Bacon.

Best, S. (2003) 'Social Theory A Beginner 's Guide to'.

Budianto, B. (2009) 30 Years Walk With Jesus. Yogyakarta: Andi Offset.

Giddens, A. (no date) 'The Sociology of'. Hudjolly (2015) Imagologi (Strategi Rekayasa Teks). Yogyakarta: Ar-Ruzz Media. Nugroho, P. (2003) Building Your Life" JKI Profile. Indonesia.

Purnomo, P. A. (1996) Bebas Dari Jerat Hutang. Semarang: Media Injil Kerajaan.

Satori, D. and Komariah, A. (2010) Metodologi Penelitian Kualitatif. 1st edn. Bandung: Penerbit Alfabeta.

Sugiyono (2012) Memahami Penelitian Kualitatif. Bandung: Alfabeta.

\section{Biodata Penulis}

Fibry Jati Nugroho lahir di Semarang, 9 Februari 1985. Beliau menyelesaikan program S1 di STT Sangkakala program studi Teologi, (2003-2007). Kemudian melanjutkan studi pascasarjana di UKSW program studi Sosiologi Agama (20102012) dan mengambil studi doktoral di UKSW program studi Sosiologi Agama tahun (2014-2017). Saat ini menjabat sebagai wakil ketua I STT Sangkakala Salatiga. 